\title{
Antimicrobial Activity of Essential Oil from Seeds of Carum carvi and Its Composition
}

\author{
Jaripa Begum ${ }^{1}$, M Nazrul Islam Bhuiyan ${ }^{*}$, Jasim Uddin Chowdhury' ${ }^{1}$, M Nuzmul Hoque ${ }^{1}$ and M Nural Anwar ${ }^{2}$ \\ ${ }^{1}$ Bangladesh Council of Scientific \& Industrial Research (BCSIR), Chittagong Cantonment, Chittagong 4220, Bangladesh, ${ }^{2}$ Department of \\ Microbiology, University of Chittagong, Chittagong 4331, Bangladesh
}

[Received 03 June 2008; Accepted 07 November, 2009]

\begin{abstract}
The essential oil of Carum carvi L. seeds was screened for its antimicrobial activity against ten pathogenic bacteria and six phytopathogenic fungi. The essential oil showed promising inhibitory activity against all the test bacteria, even at $2 \mu \mathrm{l} / \mathrm{disc}$. The minimum inhibitory concentration (MIC, 100-300 ppm) and minimum bactericidal concentration (MBC, 200-400 ppm) values of essential oil were determined. The antifungal screening of the essential oil showed $100 \%$ inhibition of radial mycelial growth of all the test fungi at 100 ppm. The MIC and minimum fungicidal concentration (MFC) values were found to vary from 50-300 ppm and 200-400 ppm respectively. The essential oil extracted by hydrodistillation from seeds of $C$. carvi was analyzed by gas chromatography-mass spectrometry (GC-MS). About 10 compounds had been identified in the seeds oils, accounting for more than $\mathbf{9 9 . 7 \%}$ of the oils. The main components of the seeds oil were thymol $(\mathbf{4 8 . 2 0} \%)$, o-cymene $(19.29 \%), \gamma$-terpinen $(17.61 \%)$ and trimethylene dichloride $(\mathbf{8 . 8 1} \%)$.
\end{abstract}

Keywords: Antimicrobial activities, Carum carvi, Essential oil, GC-MS, Thymol

\section{Introduction}

Caraway (Carum carvi L.) is a widely cultivated spice native to Europe, Asia and North Africa. It also appears wild in Iceland, Scandinavia, throughout Russia, in Siberia, Persia, the Caucasus and the Himalayas ${ }^{1-3}$. The renowned Greek physician Dioscorides suggested the oil was an excellent remedy for pale-faced girls. In addition, studies have shown that caraway oil has antibacterial and larvicidal properties ${ }^{4}$. Caraway has a long history of use as a household remedy especially in the treatment of digestive complaints where its antispasmodic action soothes the digestive tract and its carminative action relieves bloating caused by wind and improves the appetite ${ }^{5-7}$. It is often added to laxative medicines to prevent griping ${ }^{6}$. The seed is antiseptic, aromatic, anaesthetic, anodyne, antianxiety, diuretic, mildly expectorant, fungicidal, muscle relaxant, soporific, tonic, emmenagogue, expectorant, galactogogue and stimulant ${ }^{5,8-11}$. It can be chewed raw for the almost immediate relief of indigestion and can also be made into infusions ${ }^{6}$. The seed is also used in the treatment of bronchitis and are an ingredient of cough remedies, especially useful for children and for mothers for increasing breast milk ${ }^{7}$. A tea made from the seeds is a pleasant stomachic and carminative, it has been used to treat flatulent colic ${ }^{11-12}$. The seed is used in Tibetan medicine where it is considered to have an acrid taste and a heating potency. It is used to treat failing vision and loss of appetite ${ }^{13}$. An essential oil from the seed is used in perfumery, for scenting soap, as a parasiticide etc. ${ }^{8,14-15}$.
The main components of $C$. carvi oil are carvone, limonene, germacrene D, and trans-dihydrocarvone ${ }^{4}$. Gas chromatography GC and gas chromatography-mass spectrometry (GC-MS) studies showed the presence of carvone (60\%) and limonene (35\%) as the major chemical constituents of the essential oil of C. carvi ${ }^{16}$. Arganosa et $a l .{ }^{17}$ reported the major chemical constituents of the seed oil is carvone. The herb oil of caraway was found to consist of germacrene D (75\%) with â-caryophyllene, â-elemene, humulene, germacrene $\mathrm{A}$ and $\mathrm{B}$, and two cadinenes ${ }^{18}$. The essential oil content may vary between 2 and $7 \%$ of the air dried fruit weight ${ }^{1}$. Seed content of carvone varies between 1.3 and $3.5 \%$. Caraway seeds contained the main components divided into carvone (47-62\%) and limonene $(34-50 \%)^{19}$.

There is paucity of information regarding the antimicrobial activity and composition of the essential oil of caraway seeds in Bangladeshi local variety. Considering the above facts the present work has been undertaken to study antimicrobial activity of C. carvi seeds essential oil and its compositions of local variety.

\section{Materials and Methods}

Plant material

Carum carvi (caraway) seeds materials were collected from the experimental fields of BCSIR Laboratories, Chittagong, during December 2007. One voucher specimen (J-421) was deposited in the herbarium of BCSIR Laboratory, Chittagong. 


\section{Extraction of essential oil}

The collected materials were crashed, dried and then grinned. The grinned materials were soak in distil water. This water mixture is placed with Clevenger-type apparatus. The materials were hydrodistilled using Clevenger-type apparatus ${ }^{20}$. Distillation of the materials was run for $4 \mathrm{~h}$. The oil collected was then dried over anhydrous sodium sulphate and their physical characters like colour and odour were recorded. The oils were then stored in sealed container under refrigeration prior to analysis.

\section{Determination of antimicrobial activity of essential oil}

The essential oil obtained from $C$. carvi was tested for its antibacterial activity against ten potential pathogenic bacteria, viz., Bacillus subtilis BTCC 17, B. cereus BTCC 19, Escherichia coli ATCC 25922, Pseudomonas aeruginosa CRL (ICDDR, B), Shigella dysenteriae AE 14396, S. sonnei CRL. (ICDDR, B), Salmonella typhi AE 14612, S. paratyphi AE 14613, Staphylococcus aureus ATCC 6538 and Vibrio cholerae, AE 14748, and six phytopathogenic fungi, viz., Alternaria alternata (Fr.) Kedissler., Botryodiplodia theobromae pat., Colletotrichum corchori Ikata (Yoshida), Curvularia lunata (Wakker) Boedijin, Fusarium equiseti (Corda) Saccc. and Macrophomina phaseolina (Maubl) Ashby.

\section{Antibacterial activity}

The in vitro sensitivity of the bacteria to the test materials was done by disc diffusion method ${ }^{21}$. Mueller-Hinton medium was used for culture of bacteria. Each experiment was repeated thrice. All the results were compared with the standard antibacterial antibiotic ampicillin (20 ìg/disc, BEXIMCO Pharma Bangladesh Ltd., Dhaka).

\section{Antifungal activity}

In vitro antifungal activities of the essential oil of $C$. carvi seeds and nystatin were determined by poisoned food technique ${ }^{22}$. Sabouraud agar medium was used for culture of fungi. Linear mycelial growth of fungus was measured after 3-5 days of incubation. The percentage inhibition of radial mycelial growth of the test fungus was calculated as follows:

$$
\mathrm{I}=\frac{\mathrm{C}-\mathrm{T}}{\mathrm{C}} \times 100
$$

Where, $\mathrm{I}$ = percentage of inhibition; $\mathrm{C}$ = diameter of the fungal colony in the control and $\mathrm{T}=$ diameter of the fungal colony in treatment. All the results were compared with the standard antifungal antibiotic Nystatin (100 ppm). A control set was also maintained in each experiment. Each experiment was repeated thrice. The essential oil and standard antifungal and antibacterial agents were dissolved separately in specific volume of $30 \%$ dimethyl sulfoxide (DMSO) before used.

Determination of the MIC and the MBC

The minimum inhibitory concentration (MIC), minimum bactericidal concentration (MBC) and minimum fungicidal concentration (MFC) values of essential oil against 10 test bacteria were determined by micro- and macrodillution broth technique ${ }^{23}$ using Mueller-Hinton medium .The MIC and MFC values of essential oil against six test fungi were also determined by microand macrodilution broth technique ${ }^{23}$ using Sabouraud medium. During MIC, MBC and MFC experiments, essential oil of 50 to 500 ppm concentrations were used.

\section{GC-MS analysis of C. carvi essential oil}

The essential oils from rhizomes of $C$. carvi was analyzed by gas chromatography-mass spectrometry (GC-MS) electron impact ionization (EI) method on GC-17A gas chromatograph (Shimadzu, Japan) coupled to a GC-MS QP 5050A mass spectrometer (Shimadzu, Japan); fused silica capillary column (30 m x 2.5 mm; $0.25 \mathrm{~mm}$ film thickness), coated with DB-1 (J\&W); column temperature $100^{\circ} \mathrm{C}(2 \mathrm{~min})$ to $250^{\circ} \mathrm{C}$ at the rate of $3^{\circ} \mathrm{C} / \mathrm{min}$; carrier gas, helium at constant pressure of $90 \mathrm{kPa}$. Acquisition parameters full scan; scan range 40-350 amu. The essential oil composition was identified by comparing the mass spectra from NIST Library (NIST 147 and NIST 27).

\section{Results and Discussion}

The essential oil from the seeds of $C$ carvi was screened for their antibacterial activity against pathogenic bacteria and compared to that of standard antibacterial antibiotic ampicillin. The results of the sensitivity test are shown in the Table 1. Inhibition zone of 27 to $45 \mathrm{~mm}$ was recorded even at $2 \mu \mathrm{l} /$ disc concentration. The inhibitions were found better against all test bacteria except for $S$. dysenterae, which was equal to standard ampicillin. The MIC value of the essential oil varied between 100 and 300 ppm against the test bacteria. The essential oil showed the lowest MIC value (100 ppm) against S. dysenterae. The MBC values of essential oil varied between 200 and 400 ppm against test bacteria. The oil exhibited lowest MBC value (200 ppm) against $S$. dysenterae and V. cholerae. The results are in concurrence with the results of the essential oils of other plants reported by many authors ${ }^{24-27}$.

The antifungal activity of essential oil of $C$. carvi against six fungi was recorded and the results are presented in the Table 2. Hundred percent radial mycelial growth inhibition was recorded against the all six test fungi at a concentration of $100 \mathrm{ppm}$, which was far better than that of the standard nystatin. The MIC values were found to vary from 50 to 300 ppm against the test fungi (Table 3). The essential oil of $C$. carvi exhibited the lowest MIC values (50 ppm) against A. alternata, C. lunata, B. theobromae and $M$. phaseolina. The MFC values of the essential oil were found to vary between 200 and 400ppm (Table 4). The oil exhibited the lowest MFC values (200 ppm) against all the test fungi except $C$. corchori (400 ppm). Similar antifungal activities of essential oils of other plants have also been reported by many authors $28-29$. 
Table 1. Antibacterial activity of essential oil of Carum carvi seeds

\begin{tabular}{|c|c|c|c|c|c|}
\hline \multirow[t]{3}{*}{ Bacterium } & \multicolumn{5}{|c|}{$\begin{array}{c}\text { Antibacterial activity } \\
\text { (Diameter of zone of inhibition in mm) }\end{array}$} \\
\hline & \multicolumn{4}{|c|}{ Essential oil ( $\mu \mathrm{l} /$ disc) } & \multirow{2}{*}{$\begin{array}{l}\text { Ampicillin } \\
(20 \mu \mathrm{g} / \mathrm{disc})\end{array}$} \\
\hline & 2 & 5 & 10 & 15 & \\
\hline \multicolumn{6}{|l|}{ Gram-positive organism } \\
\hline Bacillus cereus & 30 & 35 & 38 & 43 & 22 \\
\hline Bacillus megaterium & 38 & 42 & 47 & 52 & 22 \\
\hline Bacillus subtilis & 38 & 40 & 43 & 46 & 25 \\
\hline Staphylococcus aureus & 29 & 34 & 38 & 45 & 20 \\
\hline \multicolumn{6}{|l|}{ Gram-negative organism } \\
\hline Escheriachia coli & 31 & 33 & 36 & 40 & 13 \\
\hline Pseudomonas species & 29 & 32 & 36 & 41 & 19 \\
\hline Salmonella typhi & 27 & 32 & 35 & 39 & 30 \\
\hline Shigella dysenteriae & 35 & 39 & 42 & 46 & 35 \\
\hline Shigella sonnei & 45 & 48 & 52 & 59 & 30 \\
\hline Vibrio cholerae & 35 & 38 & 42 & 47 & 24 \\
\hline
\end{tabular}

Table 2. Minimum inhibitory concentration (MIC) and minimum bactericidal concentration (MBC) and minimum fungicidal concentration (MFC) of essential oil from C. carvi seeds against 10 bacterial tests organisms

\begin{tabular}{|c|c|c|c|c|c|c|c|c|}
\hline \multirow[t]{2}{*}{ Bacterium } & \multicolumn{8}{|c|}{$\begin{array}{l}\text { Bacterial growth in Mueller-Hinton broth } \\
\text { (Essential oil concentration ppm) }\end{array}$} \\
\hline & 50 & 100 & 200 & 300 & 400 & 500 & MIC (ppm) & MBC (ppm) \\
\hline \multicolumn{9}{|l|}{ Gram-positive organism } \\
\hline Bacillus cereus & + & + & + & - & - & - & 300 & 400 \\
\hline Bacillus subtilis & + & + & - & - & - & - & 200 & 300 \\
\hline Bacillus megaterium & + & + & - & - & - & - & 200 & 300 \\
\hline Staphylococcus aureus & + & + & + & - & - & - & 300 & 400 \\
\hline \multicolumn{9}{|l|}{ Gram-negative organism } \\
\hline Escheriachia coli & + & + & - & - & - & - & 200 & 300 \\
\hline Pseudomonas sp. & + & + & + & - & - & - & 300 & 400 \\
\hline Salmonella typhi & + & - & - & - & - & - & 200 & 300 \\
\hline Salmonella paratyphi & + & + & - & - & - & - & 200 & 300 \\
\hline Shigella dysenteriae & + & - & - & - & - & - & 100 & 200 \\
\hline Vibrio cholerae & + & + & - & - & - & - & 200 & 200 \\
\hline
\end{tabular}

$(+)$ = Growth; $(-)=$ No growth

Table 3. Antifungal activity of essential oil of Carum carvi seeds

\begin{tabular}{|c|c|c|c|c|c|}
\hline \multirow[t]{3}{*}{ Fungus } & \multicolumn{5}{|c|}{$\begin{array}{c}\text { Antifungal activity } \\
\text { (Percent radial mycelial growth inhibition) }\end{array}$} \\
\hline & \multicolumn{4}{|c|}{ Essential oil (ppm) } & \multirow[b]{2}{*}{ Nystatin (100 ppm) } \\
\hline & 100 & 250 & 500 & 750 & \\
\hline Alternaria alternata & 100 & 100 & 100 & 100 & 56 \\
\hline Botryodiplodia theobromae & 100 & 100 & 100 & 100 & 82 \\
\hline Colletotrichum corchori & 100 & 100 & 100 & 100 & 42 \\
\hline Curvularia lunata & 100 & 100 & 100 & 100 & 72 \\
\hline Fusarium equiseti & 100 & 100 & 100 & 100 & 46 \\
\hline Macrophomina phaseolina & 100 & 100 & 100 & 100 & 71 \\
\hline
\end{tabular}


Table 4. Minimum inhibitory concentration (MIC) and minimum bactericidal concentration (MBC) and minimum fungicidal concentration (MFC) of essential oil from C. carvi seeds against six fungal tests organisms

\begin{tabular}{|c|c|c|c|c|c|c|c|c|}
\hline \multirow[t]{2}{*}{$\begin{array}{l}\text { Fungus } \\
\text {. }\end{array}$} & \multicolumn{6}{|c|}{$\begin{array}{c}\text { Fungal growth in Sabouraud broth medium } \\
\text { (Essential oil concentration in ppm) }\end{array}$} & \multirow{2}{*}{$\begin{array}{c}\text { MIC } \\
(\mathrm{ppm})\end{array}$} & \multirow{2}{*}{$\begin{array}{l}\text { MFC } \\
(\mathrm{ppm})\end{array}$} \\
\hline & 50 & 100 & 200 & 300 & 400 & 500 & & \\
\hline Alternaria alternata & - & - & - & - & - & - & 50 & 200 \\
\hline Botryodiplodia theobromae & - & - & - & - & - & - & 50 & 200 \\
\hline Colletotrichum corchori & + & + & + & - & - & - & 300 & 400 \\
\hline Curvularia lunata & - & - & - & - & - & - & 50 & 200 \\
\hline Fusarium equiseti & + & - & - & - & - & - & 100 & 200 \\
\hline Macrophomina phaseolina & - & - & - & - & - & - & 50 & 200 \\
\hline
\end{tabular}

$(+)$ = Growth; $(-)=$ No growth

Essential oil from the seeds of C. carvi from Bangladesh was analyzed by GC-MS. The oil yield was $0.80 \%$ respectively. Table 5 reported the composition of the seeds oils of $C$. carvi. Ten compounds were identified in seeds oil, which were characterized by the presence of a high content of thymol (48.20\%), o-cymene (19.29\%), $\gamma$-terpinen (17.61\%), trimethylene dichloride (8.81\%), $\beta$ pinene (3.08\%), 2-(1-cyclohexenyl) cyclohexanone (0.68\%), $\beta$ phellandrene (0.67\%), 3-carene (0.57\%), $\alpha$-thujene (0.55\%) and linalool (0.54\%). Results showed that the seeds oil was a complex mixture of numerous compounds; many of which are present in trace amounts. It is worth mentioning here that there is great variation in the chemical composition of the seeds of $C$. carvi oils. Thymol (48.20\%) is the most important and main component in seeds oil but it is totally absent in all the reported oils.

Table 5. Constituents of seeds essential oil of Carum carvi

\begin{tabular}{lc}
\hline Name of constituent & Amount (\%) \\
\hline$\alpha$-Thujene & 0.55 \\
$\beta$-Pinene & 3.08 \\
o-Cymene & 19.29 \\
$\beta$-Phellandrene & 0.67 \\
$\gamma$-Terpinen & 17.61 \\
3-Carene & 0.57 \\
Linalool & 0.54 \\
2-(1-Cyclohexenyl)cyclohexanone & 0.68 \\
Thymol & 48.20 \\
Trimethylene dichloride & 8.81 \\
\hline
\end{tabular}

So, we conclude that thymol is the first reported component in $C$. carvi seed oils. Comparison of seeds oil of Bangladesh with those reported from different region of the world showed that our oil is especially different to others ${ }^{4,17-19}$. Carvone and limonene, which have been reported as major constituents in the seeds oil, were absent in our oil. This confirms that the variation in the cultivar reported is not due to geographic divergence and ecological conditions but it is due to different chemotype. On the basis of above fact it may be concluded that $C$. carvi growing widely in Bangladesh, may be utilized as a source of natural thymol.

\section{References}

1 Toxopeus H \& Bouwmeester HJ. 1993. Improvement of caraway essential oil and carvone production in The Netherlands. Ind Crops Prod. 1: 295-301.

2. Halva S, Hirvi T, Makinen S \& Honkanen E. 1986. Yield and glucosinolates of mustard seeds and volatile oils of caraway seeds and coriander fruit. II Yield and volatile oils of caraway seeds (Carum carvi). J Agric Sci Finland. 58:163-167.

3. Hornok L. 1985. Effect of environmental factors on growth, yield and the active principles of some spice plants. Fifth International Symposium on Medicinal, Aromatic and Spice Plants, pp 169-176. Mungpoo, Darjeeling.

4. Iacobellis NS, Cantore PL, Capasso F \& Senatore F. 2005. Antibacterial activity of Cuminum cyminum L. and Carum carvi L. essential oils. J Agric Food Chem. 53(1): 57-61.

5. Grieve M. 1984. A Modern Herbal. Penguin Books, Harmondsworth, London.

6. Bown D. 1995. Encyclopaedia of Herbs and Their Uses. Dorling Kindersley, London.

7. Chevallier A. 1996. The Encyclopedia of Medicinal Plants. Dorling Kindersley. London.

8. Chiej R. 1984. Encyclopaedia of Medicinal Plants. MacDonald, Edinburgh.

9. Launert E. 1981. Edible and Medicinal Plants. Hamlyn, London.

10. Lust J. 1983. The Herb Book. Bantam Books, New York.

11. Foster S \& Duke JA. 1990. A Field Guide to Medicinal Plants: Eastern and Central North America. Houghton Mifflin Co, Boston.

12. Coffey T. 1993. The History and Folklore of North American Wild Flowers. Facts on File, New York.

13. Tsarong TJ. 1994. Tibetan Medicinal Plants, $1^{\text {st }}$ edn. Tibetan Medical Publications, Darjeeling.

14. Vasil IT .1970. Cruciferae. In Flora of the USSR (Komarov VL ed), p 240. Israel Program for Scientific Translations, Jerusalem.

15. Hill AF. 1952. Economic Botany. The Maple Press, Pennsylvania.

16. Tewari M \& Mathela CS. 2003. Compositions of the essential oils from seeds of Carum carvi Linn. and Carum bulbocastanum Koch. Indian Perfumer. 47: 347-349.

17. Arganosa GC, Sosulski FW \& Slinkard AE. 1998. Seed yields and essential oils of annual and biennial caraway (Carum carvi L.) grown in Western Canada. J Herbs Spices Med Plants. 6(1): 9-17.

18. Wichtmann EM \& Stahl-Biskup E. 1987. Composition of the essential oils from caraway herb and root. Flav Fragr J. 2(2): 83-89. 
19. Putievsky E, Ravid U, Dudai N \& Katzir I. 1994. A new cultivar of caraway (Carum carvi L.) and its essential oil. J Herbs Spices Med Plants. 2(2): 81-84.

20. Clevenger JF. 1928. Apparatus for determination of volatile oil. J Am Pharm Assoc. 17: 341-346.

21. Bauer AW, Kirby WM, Secherris JC \& Turek M. 1966. Antibiotic susceptibility testing by standard single disc method. Am J Clin Pathol. 45(4): 493-496.

22. Grover RK \& Moore JD.1962. Toximetric studies of fungicides against brown rot organisms Sclerotina flucticola and S. laxa. Phytopathology. 52: 876-880.

23. Jones NR, Barry LA, Gavan LT \& Washington II JA. 1985. Susceptibility tests: Microdilution and macrodilution broth procedures. In Manual of Clinical Microbiology (Lennette EH, Bellows A, Hausler WJ Jr \& Shadomy HJ eds), $4^{\text {th }}$ edn, pp 972-976. American Society of Microbiology, Washington DC.

24. Begum J, Chowdhury JU, Yusuf M, Wahab MA, Ahmed K,Akhter N \& Anwar MN. 1997. Evalutation of essential oils extracted from Eucalyptus citriodora and E. camaldulensis for antimicrobial properties and their toxicity in rats. Bangladesh J Sci Indust Res. 32(4): 561-566.
25. Begum J, Chowdhury JU, Yusuf M, Wahab MA, Ahmed K, Akhter N \& Anwar MN. 1999. Antimicrobial activity of the essential oils isolated from the Ocimum americanum and Ocimum gratissimum var. Clocimum and their toxicity in white strain rats. Bangladesh $J$ Microbial. 16(2): 127-134.

26. Begum J, Dutta S, Yusuf M, Chowdhury JU, Ahmed K, Ahmed S \& Anwar MN. 2007. Antimicrobial activity of Cinnamomum tamala essential oil and its composition and toxicity on white strain rats. Bangladesh J Microbial. 24(1): 14-18.

27. Chowdhury JU, Yusuf M, Begum J, Taniya AJ, Hossain ME \& Hossain MA. 2005. Aromatic plants of Bangladesh: Composition and antimicrobial activities of leaf oil from Curcuma longa L. Indian Perfumer. 49(1): 61-65.

28. Adam K, Sivropoulou A, Kokkini S, Lanaras T \& Arsenakis M. 1998. Antifungal activities of Origanum vulgare subsp. hirtum, Mentha spicata, Lavandula angustifolia and Salvia fruticosa essential oils against human pathogenic fungi. J Agric Food Chem. 46(5): 17391745 .

29. Garg SC \& Siddiqui N. 1992. Antifungal activity of some essential oil isolates. Pharmazie. 47: 467. 